\title{
Dipeptidyl peptidase-4 inhibitor linagliptin attenuates neointima formation after vascular injury
}

Yuichi Terawaki, Takashi Nomiyama*, Takako Kawanami, Yuriko Hamaguchi, Hiroyuki Takahashi, Tomoko Tanaka, Kunitaka Murase, Ryoko Nagaishi, Makito Tanabe and Toshihiko Yanase

\begin{abstract}
Background: Recently, glucagon-like peptide-1 (GLP-1)-based therapy, including dipeptidyl peptidase-4 (DPP-4) inhibitors and GLP-1 receptor agonists, has emerged as one of the most popular anti-diabetic therapies. Furthermore, GLP-1-based therapy has attracted increased attention not only for its glucose-lowering ability, but also for its potential as a tissue-protective therapy. In this study, we investigated the vascular-protective effect of the DPP-4 inhibitor, linagliptin, using vascular smooth muscle cells (VSMCs).

Methods: Six-week-old male C57BL/6 mice were divided into control $(n=19)$ and linagliptin (3 mg/kg/day, $n=20)$ treated groups. Endothelial denudation injuries were induced in the femoral artery at 8 weeks of age, followed by evaluation of neointima formation at 12 weeks. To evaluate cell proliferation of rat aortic smooth muscle cells, a bromodeoxyuridine (BrdU) incorporation assay was performed.

Results: Linagliptin treatment reduced vascular injury-induced neointima formation, compared with controls $(p<0.05)$. In these non-diabetic mice, the body weight and blood glucose levels did not change after treatment with linagliptin. Linagliptin caused an approximately 1.5-fold increase in serum active GLP-1 concentration, compared with controls. In addition, the vascular injury-induced increase in the oxidative stress marker, urinary 8-OHdG, was attenuated by linagliptin treatment, though this attenuation was not statistically significant ( $p=0.064$ ). Moreover, linagliptin did not change the serum stromal cell-derived factor-1a (SDF-1a) or the serum platelet-derived growth factor (PDGF) concentration. However, linagliptin significantly reduced in vitro VSMC proliferation.
\end{abstract}

Conclusion: Linagliptin attenuates neointima formation after vascular injury and VSMC proliferation beyond the glucose-lowering effect.

Keywords: DPP-4 inhibitor, Linagliptin, Neointima formation, VSMC proliferation

\section{Background}

Patients with diabetes mellitus have a greater risk of cardiovascular events compared with non-diabetic subjects [1], and they frequently experience restenosis after coronary angioplasty, even if intervention is performed with currently established drug-eluting stents [2]. Consequently, the aim of glycemic control is not only lowering the blood glucose level, but also improving quality of life and mortality by preventing the occurrence and progression of

\footnotetext{
* Correspondence: tnomiyama@fukuoka-u.ac.jp

Department of Endocrinology and Diabetes Mellitus, School of Medicine, Fukuoka University, 7-45-1 Nanakuma, Jonan-ku, Fukuoka 814-0180, Japan
}

vascular complications. Thus, it is important to investigate the vascular-protective effect of anti-diabetic agents.

Incretins, glucagon-like peptide-1 (GLP-1) and glucosedependent insulinotropic polypeptide (GIP) act on pancreatic $\beta$ cells to stimulate glucose-responsive insulin secretion, but also have tissue-protective effects beyond lowering blood glucose levels [3], such as cardiovascular protection [4], anti-hepatic steatosis [5] and antiAlzheimer's disease [6].

GLP-1-based therapy, which includes dipeptidyl peptidase-4 (DPP-4) inhibitors and GLP-1 receptor agonists, has become a popular treatment for patients with type 2 diabetes. Indeed, the DPP-4 inhibitor is one of the 
most prescribed anti-diabetic agents in Japan, because of its efficacy and safety [7]. Pooled analysis of clinical studies revealed that sitagliptin has a good tolerability in elderly patients with type 2 diabetes [8], with a lower rate of cardiovascular-related events compared with sulphonylurea [9]. Linagliptin is a newly identified, biliary excreted DPP-4 inhibitor, which has recently been approved as a once-daily oral glucose-lowering agent [10]. Similar to sitagliptin, the cardiovascular safety of linagliptin has been suggested to be acceptable in high-risk patients [11], and its efficacy and safety are acceptable as an add-on therapy to metformin and sulphonylurea [12]. Interestingly, in retrospective analysis, linagliptin reduced cardiovascular events compared with other glucoselowering agents [13]. Several experiments have revealed that the vascular-protective effect of linagliptin involves incretin-dependent and -independent mechanisms, such as anti-oxidative stress [14], inhibition of advanced glycation end products (AGE) and the receptor for AGE axis [15], and inhibition of vascular DPP-4 activity [16]. On the other hand, we have previously reported the vascular-protective effects of exendin-4, a GLP-1R agonist, including attenuation of atheroma formation in apoE-deficient mice via inhibition of NFKB activation in macrophages [17], and reduction of neointima formation after vascular injury via $5^{\prime}$ AMP-activated protein kinase activation in VSMCs [18]. Furthermore, we have recently demonstrated the anticancer effect of exendin-4 using a prostate cancer model [19]. However, recent clinical studies have unfortunately failed to prove cardiovascular benefits of DPP-4 inhibitors in patients with prior cardiovascular events using saxagliptin [20] or alogliptin [21]. These data prompted us to examine whether the DPP-4 inhibitor, linagliptin, can attenuate neointima formation after vascular injury, which is one of the experimental models for coronary restenosis after coronary angioplasty. Furthermore, currently there are no reports on whether linagliptin can attenuate neointima formation and VSMC proliferation after vascular injury. Thus, we examined the vascular-protective effect of linagliptin, using a VSMC proliferation model both in vivo and in vitro.

\section{Methods}

\section{Animals}

The study protocol was reviewed and approved by the Animal Care and Use Committee of Fukuoka University. Six-week-old male C57BL/6 mice were purchased from Oriental Yeast (Tokyo, Japan). All mice were housed in a polycarbonate cage with a wooden chip mat on the floor, and water was available ad libitum. C57BL/6 mice were divided into two groups, control $(n=19)$ and linagliptin treatment $(\mathrm{n}=20)$, which was kindly provided by Boehringer Ingelheim Pharma GmbH \& Co. KG (Biberach an der Riss, Germany). At 6 weeks of age, control mice were fed normal chow (22.6\% protein, $53.8 \%$ carbohydrate, $5.6 \%$ fat, $6.6 \%$ mineral and vitamin mixture, and $3.3 \%$ fiber; in total: $356 \mathrm{kcal} / 100 \mathrm{~g}$ ) with vehicle, and linagliptin-treated mice were fed normal chow with linagliptin $(0.083 \mathrm{~g} / \mathrm{kg}$ chow, which results in a mean plasma level of 50-150 nM, corresponding to an oral dose of $3 \mathrm{mg} / \mathrm{kg} /$ day) for 6 weeks. The animal room was kept on a 12-h light/dark cycle at a constant temperature $\left(22 \pm 1^{\circ} \mathrm{C}\right)$ and relative humidity of $55 \pm 5 \%$ throughout the experimental period. Endothelial denudation injuries were induced in the femoral artery at 8 weeks of age, followed by evaluation of neointima formation at 12 weeks of age.

\section{Guidewire-induced endothelial denudation injury}

Mouse femoral artery endothelial denudation injury was induced in C57BL/6 mice of the control and linagliptin groups at 8 weeks of age, as previously described [18,22]. Briefly, endovascular injury was induced by four passages of a $0.25-\mathrm{mm}$ SilverSpeed-10 hydrophilic guidewire (Micro Therapeutics Inc., Irvine, CA, USA) into the left femoral artery. Sham surgery without injury was performed on the contralateral right side. Mice were euthanized 4 weeks after injury, and femoral arteries were isolated for tissue analysis.

\section{Tissue preparation and morphometry}

Following sacrifice, mice were perfused via a cannula in the left ventricle with phosphate-buffered saline for $5 \mathrm{~min}$, followed by $4 \%$ paraformaldehyde for $30 \mathrm{~min}$ at $100 \mathrm{~cm} \mathrm{H} \mathrm{H}_{2} \mathrm{O}$. The femoral arteries were embedded in paraffin and cut into $5-\mu \mathrm{m}$ sections for further analysis. Serial sections of the $1.5-\mathrm{mm}$ proximal region from the incision site of the wire insertion and the sham surgery vessels on the other side were evaluated using an Elastica van Gieson stain kit (4033-4037, Muto Pure Chemicals Co., Tokyo, Japan), to visualize the internal elastic lamina, as previously described [18]. Specimens were viewed under a microscope (BZ9000; Keyence, Tokyo, Japan) connected to a computer. The intimal and medial areas were measured by computerized morphometry using the software BZ-II analyzer (Keyence, Tokyo, Japan). Intimal hyperplasia was defined as the formation of a neointimal layer medial to the internal elastic lamina. The medial area represents the area between the external elastic lamina and the internal elastic lamina. The intima-to-media ratio was calculated as the intimal area divided by the media area, as described previously $[18,22]$.

\section{Intraperitoneal glucose tolerance test (IPGTT)}

IPGTTs were performed on C57BL/6 mice with or without linagliptin treatment after a 12-h fast. Glucose $(2 \mathrm{~g} / \mathrm{kg})$ was administered intraperitoneally. Plasma glucose level was measured using the glucose oxidase method by a compact glucose analyzer (Glutest Neo Super, Sanwa Chemical Co., Kanagawa, Japan). 


\section{Laboratory data}

Blood samples were collected at euthanasia. Serum active GLP-1 concentration was measured using an insulin enzyme-linked immunosorbent assay (ELISA) kit (IBL, Osaka, Japan). In addition, the serum stromal cellderived factor- $1 \alpha(\mathrm{SDF}-1 \alpha)$ and platelet-derived growth factor (PDGF) concentration was measured using ELISA kits DSA00 and MBB00, respectively (R\&D Systems, Minneapolis, MN, USA). Urinary 8-hydroxy-2'-deoxyguanosine (8-OHdG) concentration was measured using a kit (JaICA, Shizuoka, Japan). Urinary creatinine levels were also measured using a kit (Wako, Osaka, Japan) to adjust the urine concentration, as previously described [23].

\section{BrdU assay}

To evaluate cell proliferation of rat aortic smooth muscle cells, the bromodeoxyuridine (BrdU) incorporation assay was performed using a Cell Proliferation ELISA kit (1647229; Roche Applied Science, Penzberg, Germany), as previously described $[18,19]$. Briefly, rat aortic smooth muscle cells were plated at 2000 cells/well in 96-well culture plates in complete media $(\mathrm{n}=5)$, and were incubated in Dulbecco's Modified Eagle Medium (DMEM) with 10\% fetal bovine serum (FBS). After attaining 60-70\% confluence, rat aortic smooth muscle cells were incubated in DMEM containing $0.1 \%$ FBS with or without $10 \mathrm{nM}$ linagliptin for $48 \mathrm{~h}$, and then stimulated with PDGF $(25 \mathrm{ng} / \mathrm{ml}$; Sigma-Aldrich, St Louis, MO, USA) or DPP-4 (200 ng/ml; R\&D Systems) for $24 \mathrm{~h}$. BrdU solution $(10 \mu \mathrm{M})$ was added during the last $2 \mathrm{~h}$ of stimulation. Next, the cells were dried and fixed, and cellular DNA was denatured with FixDenat solution (Roche Applied Science) for $30 \mathrm{~min}$ at room temperature. A peroxidase-conjugated, mouse anti-BrdU monoclonal antibody (Roche Applied Science) was added to the culture plates and incubated for $90 \mathrm{~min}$ at room temperature. Finally, tetramethylbenzidine substrate was added for $15 \mathrm{~min}$ at room temperature and absorbance of the samples was measured using a microplate reader at $450-620 \mathrm{~nm}$. Mean data are expressed as a ratio of control (non-treated) cell proliferation.

\section{Statistical analysis}

Unpaired $t$-tests were performed for statistical analysis as appropriate. $p$ values lower than 0.05 were considered to be statistically significant. Results are expressed as mean \pm SEM.

\section{Results}

\section{Linagliptin attenuates neointima formation after vascular injury}

C57BL/6 mice were treated with control or linagliptin ( $3 \mathrm{mg} / \mathrm{kg} /$ day) from 6 weeks of age to 12 weeks of age. Mouse femoral artery endothelial denudation injuries were performed at 8 weeks of age in both groups, and then neointima formation was evaluated at 12 weeks of age. Endothelial denudation injury in the control mice resulted in considerable neointima formation. In contrast, neointima formation was substantially reduced by linagliptin treatment (Figure 1A). Specifically, as shown in Figure $1 \mathrm{~B}$, quantitative analysis revealed a $60.6 \%$ reduction in neointima formation in linagliptin-treated mice compared with that in control mice, (control: $4989 \pm 1478$ vs. linagliptin: $\left.1967 \pm 894 \mu \mathrm{m}^{2}, p<0.05\right)$, although the media layer areas were not different (control: $13534 \pm 568$ vs. linagliptin: $12500 \pm 1355 \mu^{2}$ ). The intima/media (I/M) ratio was lower in the linagliptin-treated mice compared with that in the control mice, but the difference was not statistically significant (control: $0.36 \pm 0.10$ vs. linagliptin: $0.15 \pm 0.06, p=0.059$; Figure $1 \mathrm{~B}$ ). In addition, right vessels with sham surgery did not change by linagliptin treatment (Figure 1C). These data suggest that linagliptin attenuates vascular injury-induced neointima formation in vivo in non-diabetic mice.

\section{Linagliptin does not change body weight and blood glucose level in non-diabetic mice}

To investigate whether linagliptin changes body weight and blood glucose in non-diabetic mice, we measured mice body weight and performed IPGTT. As shown in Figure $2 \mathrm{~A}$ and $\mathrm{B}$, there were no differences between the control mice and the linagliptin-treated mice in body weight or glucose tolerance, suggesting that linagliptin attenuated neointima formation independent of the glucoselowering effect and body weight reduction.

\section{Linagliptin increases serum active GLP-1 concentration, but not SDF-1a and PDGF}

To examine whether orally administered linagliptin can act as a DPP-4 inhibitor to increase active GLP-1 in non-diabetic mice, we measured the serum active GLP-1 concentration in linagliptin-treated and control mice. As shown in Figure 3A, the serum active GLP-1 concentration increased by 1.5 -fold in the linagliptin-treated group compared with that in the control group (control: $14.79 \pm 0.72 \mathrm{pmol} / \mathrm{L}$ vs. linagliptin: $25.97 \pm 1.99 \mathrm{pmol} / \mathrm{L}$, $p<0.001)$. In addition to its effect on GLP-1, DPP-4 inhibitors also confer vascular protection by inducing DPP-4 substrates [24]. SDF-1 $\alpha$, which is one of the DPP-4 substrates that is degraded by DPP-4 through its cleavage [25], is a chemokine inducing endothelial progenitor cells to differentiate into endothelial cells to protect the vasculature, and increased SDF- $1 \alpha$ concentration has been reported to be a mechanism by which DPP-4 inhibitors protect the cardiovascular system [26]. Hence, we measured the serum SDF- $1 \alpha$ concentration, as described previously [27]. However, linagliptin did not increase the serum SDF-1 $\alpha$ level in mice (Figure 3B). Furthermore, the serum PDGF concentration, the most powerful proliferator 


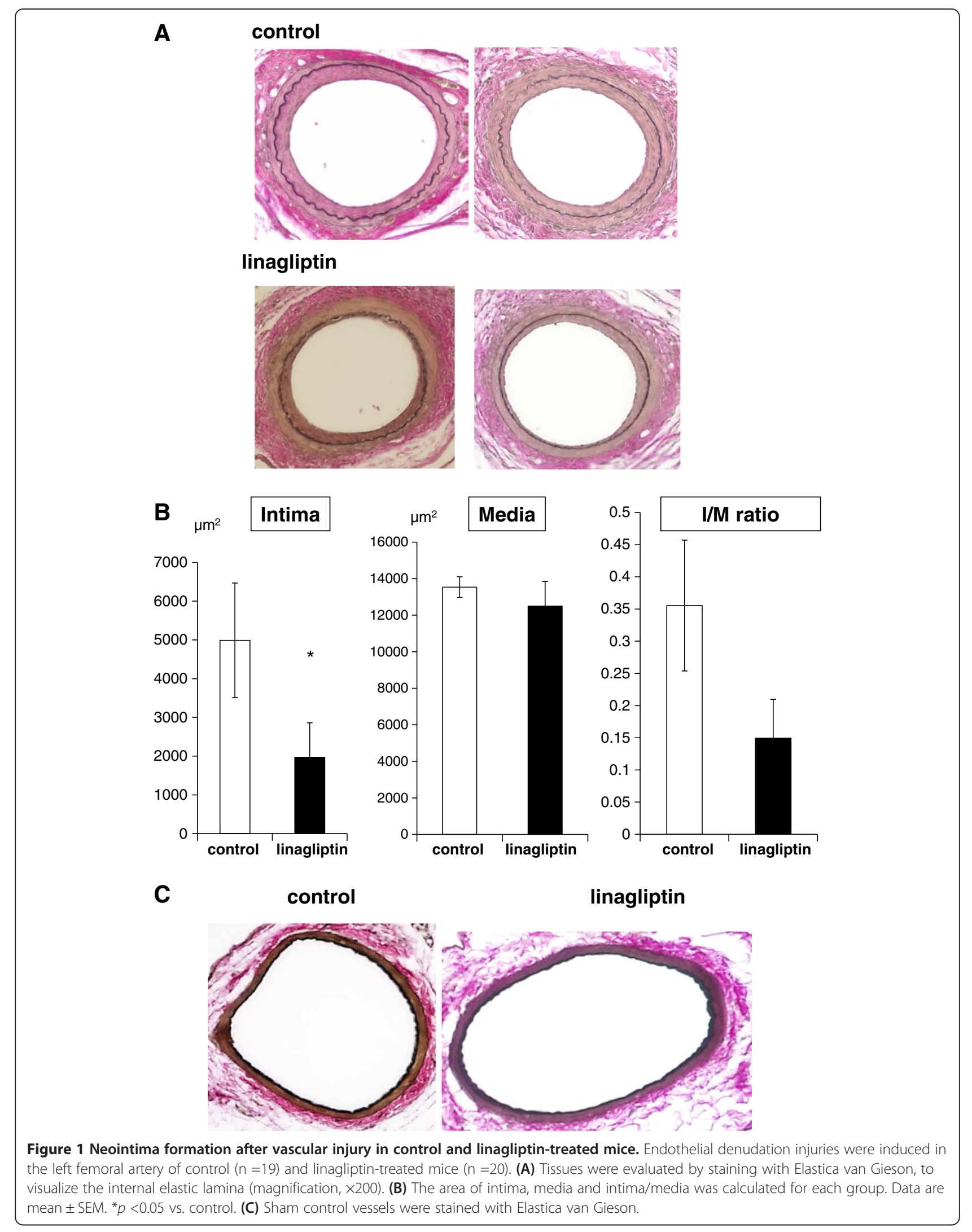




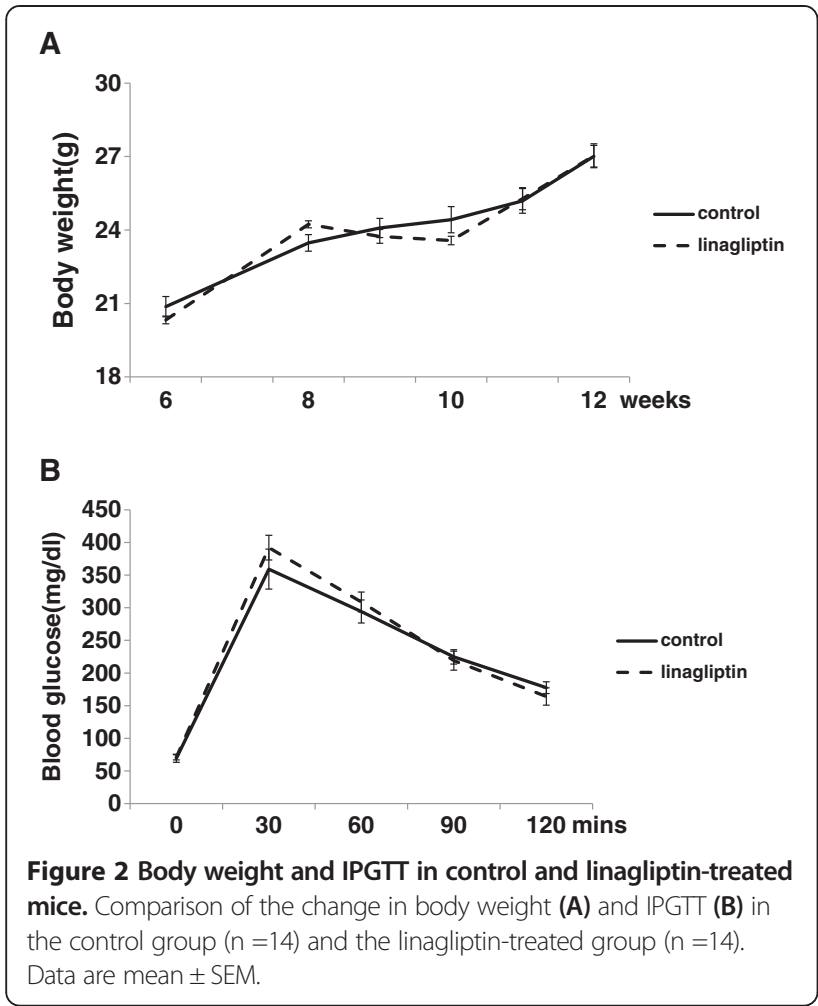

signal for VSMCs, was also unaltered by linagliptin treatment (Figure 3C). These data suggest that linagliptin increases the serum active GLP-1 concentration, but may not change other serum factors related to VSMC proliferation, including DPP-4 substrates.

\section{Linagliptin decreases urinary 8-OHdG concentration after vascular injury}

Oxidative stress is one of the most important accelerators of VSMC proliferation [28], and a previous report has suggested that linagliptin has anti-oxidative effects independent of the glucose-lowering effect [14]. Thus, we examined the oxidative stress marker, urinary 8 -OHdG, before and after vascular injury with or without linagliptin treatment. As shown in Figure 4A, the urinary 8-OHdG level was not different between the control and linagliptin-treated mice before vascular injury (control: $6.68 \pm 3.03 \mathrm{ng} / \mathrm{mgCr}$ vs. linagliptin: $5.08 \pm 2.41 \mathrm{ng} / \mathrm{mgCr}$ ). In contrast, the urinary 8-OHdG level after vascular injury decreased by linagliptin treatment (control: $39.61 \pm 23.37 \mathrm{ng} / \mathrm{mgCr}$ vs. linagliptin: $7.18 \pm 1.95 \mathrm{ng} / \mathrm{mgCr}$; Figure 4B), but not significantly $(p=0.064)$. These data suggest that anti-oxidative stress effects may be a potential mechanism by which linagliptin attenuates neointima formation after vascular injury.

\section{Linagliptin reduces VSMC proliferation in vitro}

To investigate the direct effect of linagliptin, we performed BrdU incorporation assays on rat aortic smooth

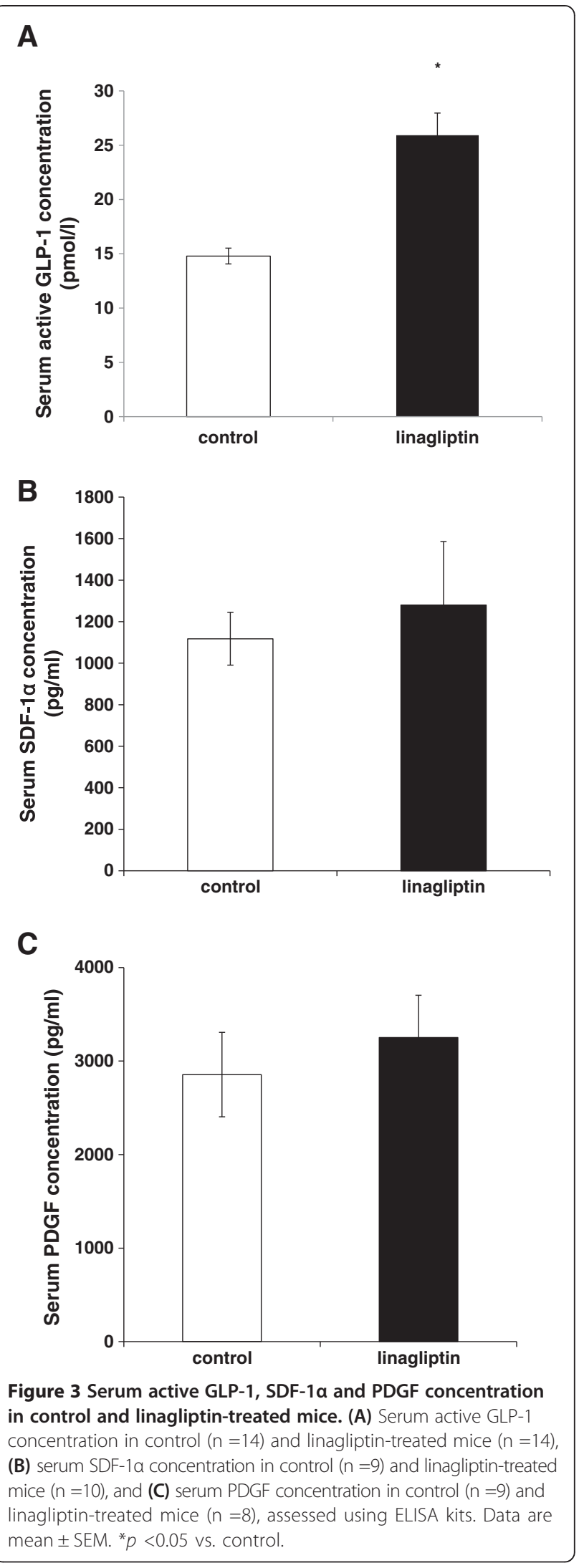




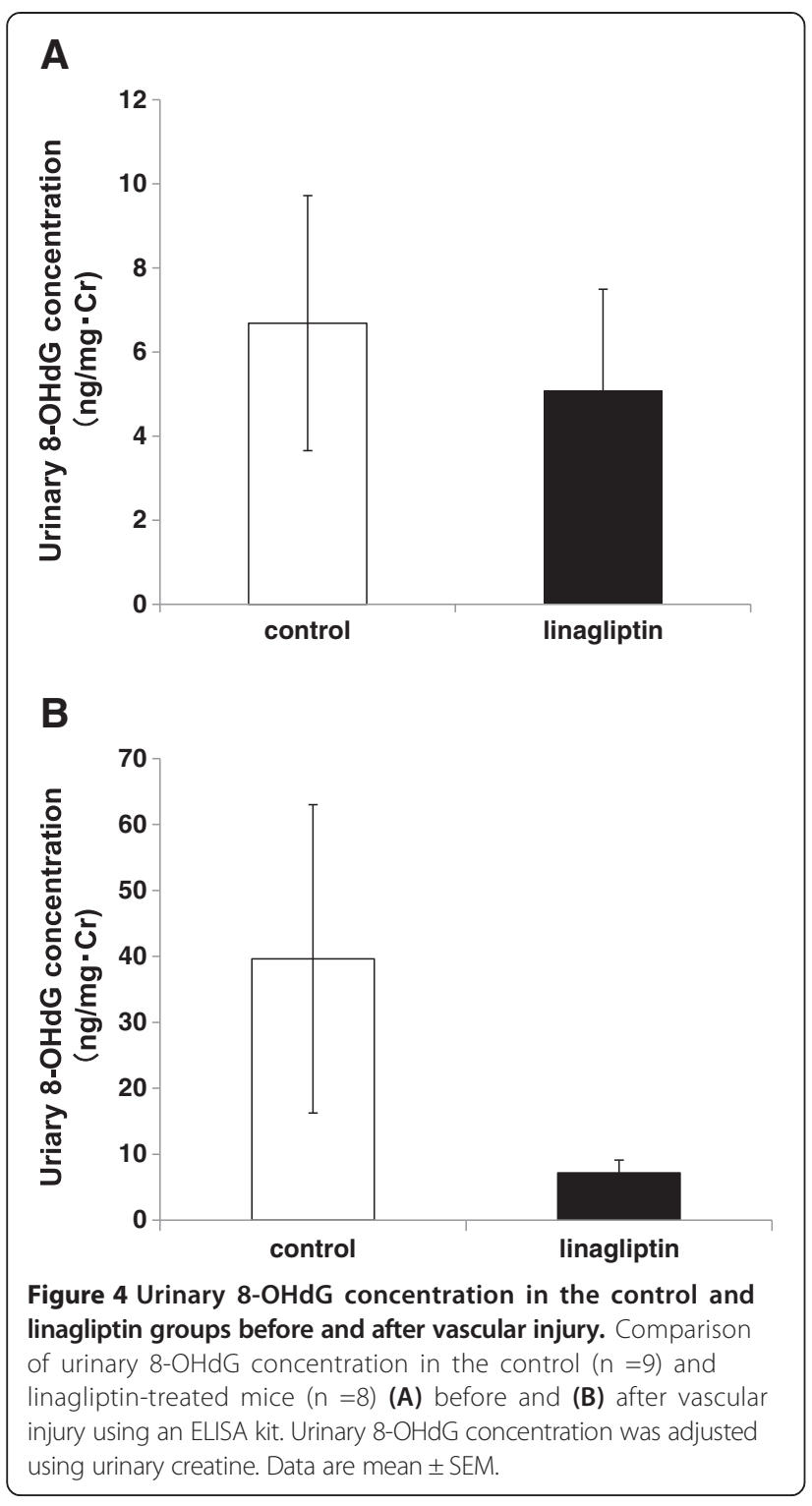

muscle cells. As shown in Figure 5, linagliptin reduced BrdU incorporation in rat aortic smooth muscle cells both with and without PDGF stimulation compared with that in the controls, suggesting that linagliptin reduces VSMC proliferation in both the quiescent and growth factor-stimulated states. Because a recent report has suggested that DPP-4 stimulates VSMC proliferation directly [29], we examined whether linagliptin attenuates DPP-4induced VSMC proliferation. As shown in Figure 5B, linagliptin attenuated DPP-4-induced VSMC proliferation.

\section{Discussion}

The present study demonstrated that the DPP-4 inhibitor, linagliptin, increased the serum active GLP-1 concentration and attenuated neointima formation after vascular injury independent of its glucose-lowering effect. Our

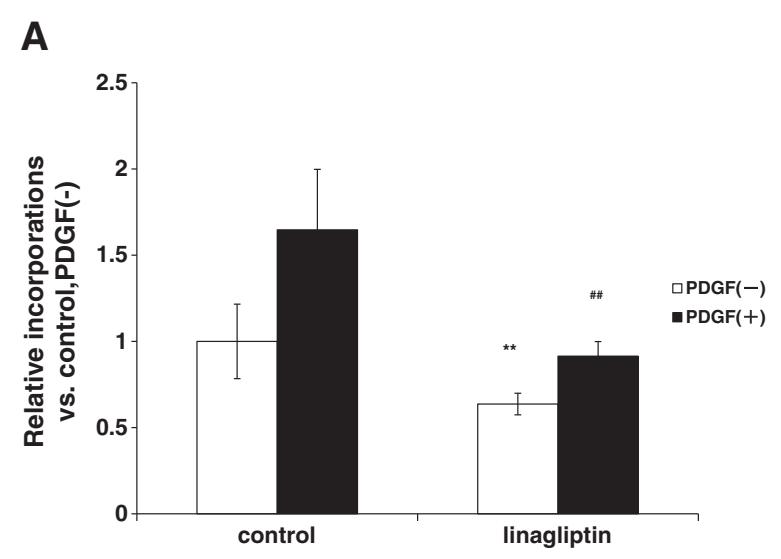

B

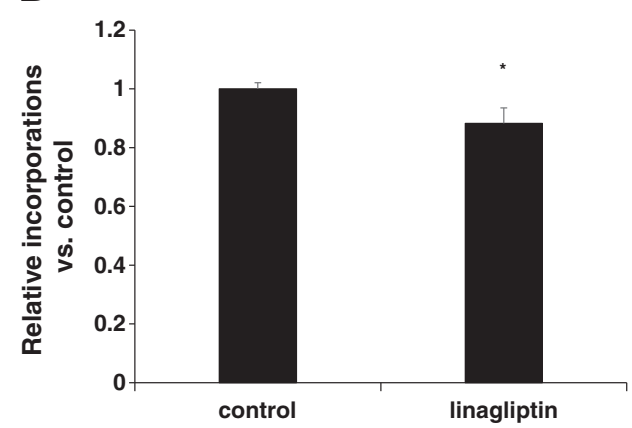

Figure 5 BrdU assay using rat aortic smooth muscle cells. (A) After rat aortic smooth muscle cells were plated, the cells were incubated in DMEM containing $0.1 \%$ FBS with or without $10 \mathrm{nM}$ linagliptin for $48 \mathrm{~h}$. Subsequently, cells were stimulated with PDGF $(25 \mathrm{ng} / \mathrm{ml})$ for $24 \mathrm{~h}$. (B) Cells were incubated in DMEM with $0.1 \%$ FBS for $24 \mathrm{~h}$. Subsequently, they were stimulated with DPP-4 (50 ng/ml) with or without $10 \mathrm{nM}$ linagliptin for $24 \mathrm{~h}$. BrdU solution was added during the last $2 \mathrm{~h}$, and cells were harvested for measurement of DNA synthesis using a microplate reader at $450-620 \mathrm{~nm}$. Mean data are expressed as the ratio of the control cell proliferation. Unpaired $t$-tests were performed to calculate statistical significance. Data are mean \pm SEM. ${ }^{* *} p<0.01$ vs. control PDGF $(-),{ }^{\# \#} p<0.01$ vs. control $\operatorname{PDGF}(+),{ }^{*} p<0.05$ vs. control.

experiments suggest the mechanisms of action include an anti-oxidative stress effect and a direct inhibitory effect of linagliptin on VSMC proliferation.

Because the aim of glycemic control is not only reduction of blood glucose level or hemoglobin A1c, but also prevention of vascular complications, it is very important to elucidate the pleiotropic or vascular-protective effect of anti-diabetic agents. GLP-1-based therapy has attracted increased attention, because of its tissueprotective effect beyond glycemic control [3-6]. Inhibition of neointima formation after vascular injury by the DPP-4 inhibitor, sitagliptin, has been reported in a rat cervical artery balloon injury model [30]. In addition, we have previously reported that the DPP-4 inhibitor, anagliptin, attenuated VSMC proliferation in non-diabetic 
apoE-deficient mice [27]. Thus, inhibition of VSMC proliferation may be one important effect of DPP-4 inhibitors. Although we have previously observed a similar anti-neointima formation effect with the GLP-1 receptor agonist, exendin- 4 , in the present study we observed other mechanisms by which linagliptin could induce vascular-protective effects independent on GLP-1. Firstly, linagliptin attenuated VSMC proliferation directly with or without growth factor and DPP-4-induced VSMC proliferation (Figure 5). Lamers et al. have reported that DPP-4 is released as an adipokine from obese visceral fat, and stimulates VSMC proliferation through extracellular signal-regulated kinase (ERK)/mitogen-activated protein kinase (MAPK) phosphorylation in VSMCs [29]. According to this report and our present data, DPP-4 inhibitors may attenuate VSMC proliferation by directly inhibiting DPP-4 independent of incretins. Secondly, linagliptin reduced oxidative stress in mice after vascular injury (Figure 4B). Linagliptin is a unique biliary excreted DPP-4 inhibitor, which has anti-oxidative stress effects because of its xanthine structure [10], long half-life and widespread tissue distribution [31]. The anti-oxidative stress effect and associated vascular protection of linagliptin is an important characteristic, because diabetic patients often have high oxidative stress that can result in atherosclerosis [32]. As we have previously reported, diabetic patients have a higher mitochondrial DNA somatic mutation ratio [33], a marker of long-term oxidative stress, which is also associated with atherosclerosis [34]. In addition, we have previously shown that oxidative stress induces further insulin resistance through tyrosine nitration of insulin receptor substrate-1, resulting in reduced glucose disposal [35]. These data suggest that oxidative stress is a key trigger of the vicious cycle between insulin resistance, hyperglycemia and vascular complications. In the present study, we observed a reduction in urinary 8-OHdG after vascular injury with linagliptin treatment, though it was not statistically significant, probably because we used non-diabetic and non-septic, normal mice.

In addition, DPP-4 cleaves not only incretins, but also other substrates such as SDF- $1 \alpha$, peptide YY, and brain natriuretic peptide (BNP) [24]. Of these substrates, SDF$1 \alpha$ is the most potent chemokine known to induce cardiovascular protection by DPP-4 inhibitors, because it has been reported that the levels of serum SDF- $1 \alpha$ and endothelial progenitor cells increased with oral DPP-4 inhibitor treatment in patients with type 2 diabetes [36]. Accordingly, we hypothesized that linagliptin attenuates neointima formation after vascular injury through induction of endothelial progenitor cells by increasing SDF$1 \alpha$. However, linagliptin did not increase the serum SDF-1 $\alpha$ levels. This is consistent with our previous report showing that anagliptin did not increase the serum
SDF-1 $\alpha$ levels in mice [27]. The difference in the results between the studies mentioned above is likely because of the different species investigated, human vs. rodent. In the present study, we could not measure other DPP-4 substrates, such as BNP [24], because of sample limitation. Further elucidation of DPP-4 substrates is required. Furthermore, Kanasaki et al. have recently reported that linagliptin inhibited the endothelial-to-mesenchymal transition in type 1 diabetic mouse kidney, independent of the glucose-lowering effect [37]. This pleiotropic effect could be a potential effect of linagliptin. In the present study, we were unable to investigate all mechanisms by which linagliptin attenuates neointima formation after vascular injury. Further studies are needed to clarify the vascularprotective effect of linagliptin.

\section{Conclusion}

The DPP-4 inhibitor, linagliptin, attenuates neointima formation after vascular injury independent of its glucoselowering effect, possibly through anti-oxidative stress effects, increasing the serum active GLP-1 concentration, attenuating DPP-4-induced VSMC proliferation and direct inhibition of VSMC proliferation.

\section{Abbreviations \\ 8OHdG: 8-hydroxy-2'-deoxyguanosine; AGE: Advanced glycation end products; BrdU: Bromodeoxyuridine; DPP-4: Dipeptidyl peptidase 4; GIP: Glucose-dependent insulinotropic polypeptide; GLP-1: Glucagon-like peptide-1; IPGTT: Intraperitoneal glucose tolerance test; PDGF: Platelet- derived growth factor; SDF-1a: Stromal cell-derived factor-1 a; VSMC: Vascular smooth muscle cells.}

\section{Competing interests}

YT received a travel grant from Boehringer Ingelheim. TN received a lecture fee from Boehringer Ingelheim and Eli Lilly. TY received a lecture fee from Eli Lilly. The other authors have no competing interests.

\section{Authors' contributions}

YT performed experiments and wrote the manuscript; TN performed experiments, wrote the manuscript and conceived the research hypothesis; TK, YH and HT performed experiments; TT, KM, RN and MT reviewed and edited the manuscript, and assisted in patient recruitment; TY assisted in conception of the research hypothesis, and reviewed and edited the manuscript. All authors read and approved the final manuscript. TN is the guarantor of this work and, as such, had full access to all the data in the study, and takes responsibility for the integrity of the data and the accuracy of data analysis.

\section{Acknowledgement}

We thank Prof. T Inoguchi and Dr. N Sonoda (Kyushu University) for technical advices.

Received: 3 September 2014 Accepted: 30 October 2014

Published online: 19 November 2014

\section{References}

1. Haffner SM, Lehto S, Ronnemaa T, Pyorala K, Laakso M: Mortality from coronary heart disease in subjects with type 2 diabetes and in nondiabetic subjects with and without prior myocardial infarction. N Eng J Med 1998, 339:229-234.

2. Scheen AJ, Warzee F: Diabetes is still a risk factor for restenosis after drug-eluting stent in coronary arteries. Diabetes Care 2004, 27:1840-1841.

3. Pratley RE, Gilbert M: Targeting Incretins in Type 2 Diabetes: Role of GLP-1 Receptor Agonists and DPP-4 Inhibitors. Rev Diabet Stud 2008, 5:73-94. 
4. Ussher JR, Drucker DJ: Cardiovascular actions of incretin-based therapies. Circ Res 2014, 114:1788-1803.

5. Ding X, Saxena NK, Lin S, Gupta NA, Anania FA: Exendin-4, a glucagon-like protein-1 (GLP-1) receptor agonists, reverses hepatic steatosis in ob/ob mice. Hepatology 2006, 43:173-181.

6. Bomfim TR, Forny-Germano L, Sathler LB, Brito-Moreira J, Houzel JC, Decker H, Silverman MA, Kazi H, Melo HM, McClean PL, Holscher C, Arnold SE, Talbot K, Klein WL, Munoz DP, Ferreira ST, De Felice FG: An anti-diabetes agent protects the mouse brain from defective insulin signaling caused by Alzheimer's disease-associated A $\beta$ oligomers. J Clin Invest 2012, 122:1339-1353.

7. Nomiyama T, Akehi Y, Takenoshita H, Nagaishi R, Terawaki Y, Nagasako H, Kudo $T$, Kodera $T$, Kobayashi $K$, Urata $H$, Yanase $T$, members of CHAT: Contributing factors related to efficacy of the dipeptidyl peptidase-4 inhibitor sitagliptin in Japanese patients with type 2 diabetes. Diabetes Res Clin Pract 2012, 95:e27-e28.

8. Round EM, Engel SS, Golm GT, Davies MJ, Kaufman KD, Goldstein BJ: Safety of sitagliptin in elderly patients with type 2 diabetes: a pooled analysis of 25 clinical studies. Drugs Aging 2014, 31:203-214.

9. Engel SS, Golm GT, Shapiro D, Davies MJ, Kaufman KD, Goldstein BJ: Cardiovascular safety of sitagliptin in patients with type 2 diabetes mellitus: a pooled analysis. Cardiovasc Diabetol 2013, 12:3.

10. Doupis J: Linagliptin: from bench to bedside. Drug Des Devel Ther 2014, 8:431-446.

11. Von Eynatten M, Gong Y, Emeser A, Woerie HJ: Efficacy and safety of linagliptin in type 2 diabetes subjects at high risk for renal and cardiovascular disease: a pooled analysis of six phase III clinical trials. Cardiovasc Diabetol 2013, 12:60.

12. Zeng Z, Yang JK, Tong N, Yan S, Zhang X, Gong Y, Woerie HJ: Efficacy and safety of linagliptin added to metformin and sulphonylurea in Chinese patients with type 2 diabetes: a sub-analysis of data from a randomized clinical trial. Curr Med Res Opin 2013, 29:921-929.

13. Johansen OE, Neubacher D, von Eynatten M, Patel S, Woerle HJ: Cardiovascular safety with linagliptin in patients with type 2 diabetes mellitus: a pre-specified, prospective, and adjudicated meta-analysis of a phase 3 programme. Cardiovasc Diabetol 2012, 11:3.

14. Kröller-Schön S, Knorr M, Hausding M, Oelze M, Schuff A, Schell R, Sudowe S, Scholz A, Daub S, Karbach S, Kossmann S, Gori T, Wenzel P, Schulz E, Grabbe S, Klein T, Münzel T, Daiber A: Glucose-independent improvement of vascular dysfunction inexperimental sepsis by dipeptidyl-peptidase 4 inhibition. Cardiovasc Res 2012, 96:140-149.

15. Ishibashi Y, Matsui T, Maeda S, Higashimoto Y, Yamagishi S: Advanced glycation end products evoke endothelial cell damage by stimulating soluble dipeptidyl peptidase- 4 production and its interaction with mannose 6-phosphate /insulin-like growth factor II receptor. Cardiovasc Diabetol 2013, 12:125.

16. Takai S, Sakonjo H, Jin D: Significance of vascular dipeptidyl peptodase-4 inhibition on vascular protection in zucker diabetic fatty rats. J Pharmacol SCi 2014, 125:386-393.

17. Arakawa M, Mita T, Azuma K, Ebato C, Goto H, Nomiyama T, Fujitani Y, Hirose T, Kawamori R, Watada H: Inhibition of monocyte adhesion to endothelial cells and attenuation of atherosclerotic lesion by a glucagon-like peptide-1 receptor agonist, exendin-4. Diabetes 2010, 59:1030-1037.

18. Goto H, Nomiyama T, Mita T, Yasunari E, Azuma K, Komiya K, Arakawa M, Jin WL, Kanazawa A, Kawamori R, Fujitani Y, Hirose T, Watada T: Exendin-4, a glucagon-like peptide-1 receptor agonist, reduces intimal thickening after vascular injury. Biochem Biophys Res Commun 2011, 405:79-84.

19. Nomiyama $T$, Kawanami T, Irie $S$, Hamaguchi $Y$, Terawaki $Y$, Murase $K$, Tsutsumi Y, Nagaishi R, Tanabe M, Hidetaka Morinaga, Tanaka T, Mizoguchi M, Nabeshima K, Tanaka M, Yanase T: Exendin-4, a glicagon-like peptide-1 receptor agonist, attenuates prostate cancer growth. Diabetes 2014, 63:3891-3905.

20. Scirica BM, Bhatt DL, Braunwald E, Steg PG, Davidson J, Hirshberg B, Ohman P, Frederich R, Wiviott SD, Hoffman EB, Cavender MA, Udell JA, Desai NR, Masenzon O, McGuire DK, Ray KK, Leiter LA, Raz I: SAVOR-TIMI 53 Steering Committee and Investigators: Saxagliptin and cardiovascular outcomes in patients with type 2 diabetes mellitus. N Eng J Med 2013, 369:1317-1326.

21. White WB, Cannon CP, Heller SR, Nissen SE, Bergenstal RM, Bakris GL, Perez AT, Fleck PR, Mehta CR, Kupfer S, Wilson C, Cushman WC, Zannad F, EXAMIN Investigators: Alogliptin after acute coronary syndrome in patients with type 2 diabetes. N Eng J Med 2013, 369:1327-1335.
22. Nomiyama T, Zhao Y, Gizard F, Findeisen HM, Heywood EB, Jones KL, Conneely OM, Bruemmer D: Deficiency of the NR4A neuron-derived orphan receptor-1 attenuates neointima. Circulation 2009, 119:577-586.

23. Ogawa M, Isse T, Oyama T, Kunugita N, Yamaguchi T, Kinaga T, Narai R, Matsumoto A, Kim YD, Kim H, Uchiyama I, Kawamoto T: Urinary 8-Hydroxyguanosine (8-OHdG) levels and plasma malondialdehyde (MDA) levels in Aldhs knock-out mice under acetaldehyde exposure. Ind Health 2006, 44:179-183.

24. Ussher JR, Drucker DJ: Cardiovascular biology of the incretin systems. Endocrine Reviews 2012, 33:187-215.

25. Murohara T: Dipeptidyl peptidase-4 inhibitor: another player for cardiovascular protection. J Am Coll Cardiol 2012, 59:277-279.

26. Albiero M, Avogaro A, Fadini GP: Restoring stem cell mobilization to promote vascular repair in diabetes. Vascul Pharmacol 2013, 58:253-258.

27. Ervinna N, Mita T, Yasunari E, Azuma K, Tanaka R, Fujimura S, Sukmawati D, Nomiyama T, Kanazawa A, Kawamori R, Fujitani Y, Watada H: Anagliptin, DPP-4 inhibitor, suppresses proliferation of vascular smooth muscles and monocyte inflammatory reaction and attenuates atherosclerosis in male apoE-deficient mice. Endocrinology 2013, 154:1260-1270.

28. Taniyama Y, Griendling KK: Reactive oxygen species in the vasculature: molecular and cellular mechanisms. Hypertension 2003, 42:1075-1081.

29. Lamers D, Famulla S, Wronkowitz N, Hartwig S, Lehr S, Ouwens DM, Eckardt K, Kaufman JM, Ryden M, Müller S, Hanisch FG, Ruige J, Arner P, Sell H, Eckel J: Dipeptidyl peptidase 4 is a novel adipokine potentially linking obesity to the metabolic syndrome. Diabetes 2011, 60:1917-1925

30. Lim S, Choi SH, Shin H, Cho BJ, Park HS, Ahn BY, Kang SM, Yoo JW, Jang HC, Kim YB, Park KS: Effect of dipeptidyl peptidase-IV inhibitor, des-fluorositagliptin, on neointimal formation after ballon injury in rats. PLOs One 2012, 7:e35007.

31. Gologhtly LK, Drayna CC, McDermott MT: Comparative clinical pharmacokinetics of dipeptidyl peptidase-4 inhibitors. Clin Pharmacokinet 2012, 51:501-514.

32. Ceriello A: Cardiovascular effects of acute hyperglycemia: pathophysiological underpinnings. Diab Vasc Dis Res 2008, 5:260-268.

33. Nomiyama T, Tanaka Y, Hattori N, Nishimaki K, Nagasaka K, Kawamori R, Ohta S: Accumulation of somatic mutation in mitochondrial DNA extracted from peripheral blood cells in diabetic patients. Diabetologia 2002, 45:1577-1583.

34. Nomiyama T, Tanaka $Y$, Piao L, Hattori N, Uchino H, Watada H, Kawamori R, Ohta S: Accumulation of Somatic Mutation in mitochondrial DNA and Atherosclerosis in Diabetic Patients. Ann NY Acad Sci 2004, 1011:193-204.

35. Nomiyama T, Igarashi $Y$, Taka H, Mineki R, Uchida T, Ogihara T, Choi JB, Uchino H, Tanaka Y, Maegawa H, Kashiwagi A, Murayama K, Kawamori R, Watada H: Deterioration of Insulin Stimulated Glucose Uptake by Peroxynitrite is Associated with Tyrosine-nitration of Insulin Receptor Substrate-1. Biochem Biophys Res Commun 2004, 320:639-647.

36. Fadini GP, Boscaro E, Albiero M, Menegazzo L, Frison V, de Kreutzenberg S, Agostini C, Tiengo A, Avogaro A: The oral dipeptidyl peptidase-4 inhibitor sitagliptin increases circulating endothelial progenitor cells in patients with type 2 diabetes: possible role of stromal-derived factor-1 alpha. Diabetes Care 2010, 33:1607-1609.

37. Kanasaki K, Shi S, Kanasaki M, He J, Nagai T, Nakamura Y, Ishigaki Y, Kitada M, Srivastava SP, Koya D: Linagliptin-mediated DPP-4 inhibition ameliorates kidney fibrosis in streptozotocin-induced diabetic mice by inhibiting endotherial-to-mesenchymal transision in therapeutic regimen. Diabetes 2014, 63:2120-2131.

\section{doi:10.1186/s12933-014-0154-3}

Cite this article as: Terawaki et al: Dipeptidyl peptidase-4 inhibitor linagliptin attenuates neointima formation after vascular injury. Cardiovascular Diabetology 2014 13:154. 